\title{
ОЦЕНКА РЕЗУЛЬТАТОВ ИСПОЛЬЗОВАНИЯ ГОСУДАРСТВЕННОЙ СОБСТВЕННОСТИ ИРКУТСКОЙ ОБЛАСТИ
}

\author{
А. А. Ануфриева, Н. С. Девятова \\ Байкальский государственный университет, г. Иркутск, Российская Федерация
}

\section{Информация о статье}

Дата поступления

23 ноября 2017 г.

Дата принятия к печати 28 февраля 2018 г.

Дата онлайн-размещения 30 марта 2018 г.

\section{Ключевые слова}

Государственная собственность; Иркутская область; эфффективность; результативность; использование государственной собственности

\begin{abstract}
Аннотация
Статья посвящена анализу результатов использования объектов государственной собственности Иркутской области областными государственными учреждениями, областными государственными унитарными предприятиями, хозяйственными обществами, пакеты акций (доли) которых находятся в государственной собственности Иркутской области, за 2016 г. Рассмотрены показатели, позволяющие получить информацию об изменении стоимости областного имущества, о состоянии и качестве имущества, используемого для оказания услуг и выполнения работ общественно значимого характера, о профильном и целевом использовании имущества, о доходах от использования имущества, расходах на содержание имущества, источниках его прироста и обновления. Дана оценка результатам использования областного имущества, а также уровню организации сбора, обработки и представления сведений о результативности и эффективности управления государственной собственностью Иркутской области. Сделан вывод, что для повышения качества управления государственной собственностью Иркутской области необходима комплексная система контроля за использованием областной собственности, которая представляла бы собой интеграцию технических средств мониторинга, профессиональных компетенций и методической базы оценки эффективности использования объектов областной собственности.
\end{abstract}

\section{EVALUATING EFFICIENCY OF IRKUTSK OBLAST PUBLIC PROPERTY USE}

\author{
Alena A. Anufrieva, Natalia S. Devyatova \\ Baikal State University, Irkutsk, the Russian Federation
}

Article info

Received

November 23, 2017

Accepted

February 28, 2018

Available online

March 30, 2018

\section{Keywords}

Public property; Irkutsk Oblast; efficiency; results; use of public property

\begin{abstract}
The article is aimed at performing an analysis of results of 2016 Irkutsk Oblast public property use by regional state institutions, regional state unitary enterprises, business companies, some stakes (shares) of which are owned by Irkutsk Oblast. The indicators estimating changes in the cost of the regional property, character of the property used to provide public services, profile and targeted use of property, income from the use of the property, expenditures for its maintenance, sources of its growth and renewal are considered. The article evaluates the use of the regional property as well as the level of collecting, processing and providing data on the results and efficiency of Irkutsk Oblast public property management. The following conclusion is made: in order to enhance the quality of the Irkutsk Oblast public property management, a comprehensive control system over the regional property use which would integrate technical monitoring facilities, professional competencies and methodological base for evaluation of efficiency of the regional property use is required.
\end{abstract}

Государственная собственность, будучи по своей сути «народной собственностью», переданной в доверительное управление государственным органам исполнительной власти, является экономической основой исполнения государственных полномочий 
преимущественно для обеспечения предпосылок повышения уровня и качества жизни населения.

Одной из важнейших задач государства в сорере управления государственной собственностью является формирование «эффективного набора прав собственности с целью максимизации совокупного продукта общества» [1].

Государственная собственность - один из основополагающих элементов экономической системы субъекта Федерации. Однако сама по себе государственная собственность не имеет никакого экономического смысла без фрормирования внятной экономической политики по управлению ею и эфффективной системы управления [2, с. 14].

Эфрфективное управление позволяет максимизировать результаты владения, пользования и распоряжения объектами собственности в рамках законодательно установленных ограничений [3, с. 32].

Пользование оценивается относительно результативности и эффрективности использования объектов государственной собственности, переданных экономическим агентам на праве оперативного управления, хозяйственного ведения и в качестве вклада в уставный капитал государственным учреждениям, государственным унитарным предприятиям и хозяйственным обществам, пакеты акций (доли) которых находятся в государственной собственности соответственно. Эффрективное пользование объектами собственности, по мнению авторов, есть извлечение пользы (социального, экономического, бюджетного эффектов) при оптимизации бюджетных затрат в рамках передачи государственного имущества на соответствующем вещном праве.

В целом можно отметить недостаточность и некоторую «однобокость» методологических подходов к определению и оценке эфрфективности управления публичным имуществом через оценку лишь экономической и (или) бюджетной эфффективности [4, c. 19]. К настоящему времени можно считать успешно решенной лишь задачу обеспечения учета объектов. Данная система является достаточно налаженной, не требующей значительных методологических изменений. В то же время пока наиболее слабо проработаны и организованы системы мониторинга и оценки эффективности использования государственного имущества, особенно их методическая и техническая стороны [5, с. 83].

Сложившаяся практика оценки эффективности деятельности по управлению государственной собственностью больше ориентирована на отражение результативности выполняемых функций (процесса), при этом упускается анализ и оценка полученных результатов.

Крен в сторону эфрфективности процесса создает предпосылки для «работы ради работы», т. е. приводит к отрыву от конечных целей этой работы. Поэтому важно выделить зону сбалансированного потенциального успеха, где наблюдается наибольшая синергия общей эффрективности работы [6, с. 16-17].

Реализация практики предоставления отчета о распоряжении государственной собственностью Иркутской области в свободной, нерегламентированной форме привела к тому, что он стал содержать исключительно сведения о проделанной работе министерства имущественных отношений Иркутской области за отчетный период. Представляемые в отчете Законодательному собранию Иркутской области сведения не позволяли сделать комплексную оценку эффрективности и результативности управления и распоряжения областной государственной собственностью [7, с. 57-58].

Сегодня существует проблема управления государственной и муниципальной собственностью. Эффрективность этого управления оставляет желать лучшего, поэтому возникает необходимость в законодательном обеспечении эфффективного управления государственной и муниципальной собственностью, для чего необходимо структурировать и количественно оптимизировать организации и предприятия государственной и муниципальной форм собственности; обеспечить полный и своевременный учет государственной и муниципальной собственности и всех проводимых с ней операций; создать систему контроля за сохранностью государственной и муниципальной собственности и использованием ее по назначению [8, с. 132].

С целью формирования системы регулярного менеджмента в сорере управления государственной собственностью Иркутской области авторами были разработаны требования к оценке эффективности деятельности правительства Иркутской области в данной сфрере, в том числе по использованию объектов областной собственности областными государственными учреждениями, областными государственными унитарными предприятиями и хозяйственными обществами, пакеты акций (доли) которых находятся в государственной собственности. Данные требования нашли отражение в положениях закона Иркутской области «О порядке управления и распоряжения государственной 
собственностью Иркутской области» от 6 декабря 2011 г. № 123-О3.

Предложенная совокупность показателей позволяет получить общую картину изменения стоимости имущества, состояния и качества имущества, используемого для оказания услуг, профильности и целевого использования имущества, доходов от использования имущества, расходов на содержание областного имущества, источников его прироста и обновления.

В настоящей статье дана оценка результатов использования объектов областной государственной собственности Иркутской области за 2016 г. ${ }^{1}$

Так как 66,00 \% от общей стоимости объектов государственной собственности Иркутской области составляет стоимость нефинансовых активов областных государственных учреждений, 9,88 \% - областных государственных унитарных предприятий, результаты использования областной собственности именно учреждениями и унитарными предприятиями представляются наиболее значимыми для оценки эфффективности и результативности управления областной собственностью правительством Иркутской области в целом.

В соответствии с отчетом правительства Иркутской области о распоряжении госу-

1 По данным отчета правительства Иркутской области о распоряжении государственной собственностью Иркутской области за 2016 г. URL: irksp.ru>wp-content/ uploads $/ 2017 / 07 /$ bul_2017...5.pdf. дарственной собственностью Иркутской области за 2016 г. (далее - отчет) основными направлениями деятельности правительства Иркутской области в 2016 г. в сфере использования областной собственности областными государственными учреждениями стали:

- оптимизация количества учреждений и расходов областного бюджета;

- эфффективное использование средств областного бюджета;

- реформирование учреждений бюджетной системы (изменение типа);

- разработка показателей эффрективности деятельности учреждений;

- совершенствование нормативных правовых актов.

По данным отчета, совокупный объем доходов областных государственных учреждений в 2016 г. составил 44 млрд р., объем расходов регионального бюджета на содержание их имущества - около 1 млрд р.

Сведения о количестве и динамике числа областных государственных учреждений (далее - ОГУ), областных государственных унитарных предприятий (далее - ОГУП), хозяйственных обществ, пакеты акций (доли) которых находятся в государственной собственности Иркутской области (далее - ХО или хозяйственные общества), органов государственной власти Иркутской области (далее - ОГВ) по состоянию на 1 января 2017 г., а также данные о структуре и стоимости объектов областного имущества в разрезе хозяйствующих субъектов представлены в табл. 1.

Таблица 1

Сведения о составе и структуре государственной собственности Иркутской области по состоянию на 1 января 2017 г.

\begin{tabular}{|c|c|c|c|c|c|c|}
\hline \multirow{4}{*}{$\begin{array}{c}\text { Хозяйствующие } \\
\text { субъекты }\end{array}$} & \multirow{2}{*}{\multicolumn{2}{|c|}{ Число объектов учета }} & \multicolumn{4}{|c|}{ Виды объектов областной собственности } \\
\hline & & & \multirow{2}{*}{$\begin{array}{c}\text { Объекты } \\
\text { недвижимости } \\
\text { Количество } \\
\end{array}$} & \multirow{2}{*}{$\begin{array}{l}\text { Движимое } \\
\text { имущество } \\
\text { Количество }\end{array}$} & \multirow{2}{*}{\begin{tabular}{|c|}
$\begin{array}{c}\text { Земельные } \\
\text { участки }\end{array}$ \\
Количество \\
\end{tabular}} & \multirow{2}{*}{$\begin{array}{c}\begin{array}{c}\text { Пакеты акций } \\
\text { (доли) }\end{array} \\
\text { Количество }\end{array}$} \\
\hline & Всего & Абсо- & & & & \\
\hline & $\begin{array}{c}\text { юридиче- } \\
\text { ских лиц, } \\
\text { ед. }\end{array}$ & $\begin{array}{c}\text { лютный } \\
\text { прирост } \\
(+/-)\end{array}$ & $\begin{array}{l}\text { Стоимость, } \\
\text { тыс. } \mathrm{p} .\end{array}$ & $\begin{array}{l}\text { Стоимость, } \\
\text { тыс. } \mathrm{p} .\end{array}$ & $\begin{array}{l}\text { Стоимость, } \\
\text { тыс. } \mathrm{p} .\end{array}$ & $\begin{array}{l}\text { Стоимость, } \\
\text { тыс. } \mathrm{p} .\end{array}$ \\
\hline \multirow{2}{*}{$\begin{array}{l}\text { Органы государственной } \\
\text { власти }\end{array}$} & \multirow{2}{*}{73} & \multirow{2}{*}{-19} & 274 & * & * & $\times$ \\
\hline & & & 1116609 & 837248,7 & * & $x$ \\
\hline \multicolumn{7}{|c|}{ Некоммерческие организации } \\
\hline \multirow{2}{*}{$\begin{array}{l}\text { Областные государствен- } \\
\text { ные учреждения, всего }\end{array}$} & \multirow{2}{*}{575} & \multirow{2}{*}{-16} & 7994 & * & * & \multirow{2}{*}{$x$} \\
\hline & & & 82743201 & 14864128,8 & * & \\
\hline \multirow{3}{*}{$\begin{array}{l}\text { В том числе } \\
\text { Областные государ- } \\
\text { ственные бюджетные } \\
\text { учреждения }\end{array}$} & \multirow{3}{*}{269} & \multirow{3}{*}{ * } & * & * & * & \multirow{3}{*}{$\times$} \\
\hline & & & & & & \\
\hline & & & 31877036,4 & 4465566,6 & * & \\
\hline \multirow{2}{*}{$\begin{array}{l}\text { Областные государ- } \\
\text { ственные автономные } \\
\text { учреждения }\end{array}$} & \multirow[b]{2}{*}{126} & \multirow[b]{2}{*}{ * } & * & * & * & \multirow[b]{2}{*}{$\times$} \\
\hline & & & 8685812,2 & 8659497,8 & * & \\
\hline
\end{tabular}


Окончание табл. 1

\begin{tabular}{|c|c|c|c|c|c|c|}
\hline \multirow{4}{*}{$\begin{array}{c}\text { Хозяйствующие } \\
\text { субъекты }\end{array}$} & \multirow{2}{*}{\multicolumn{2}{|c|}{ Число объектов учета }} & \multicolumn{4}{|c|}{ Виды объектов областной собственности } \\
\hline & & & \multirow{2}{*}{$\begin{array}{c}\text { Объекты } \\
\text { недвижимости } \\
\text { Количество } \\
\end{array}$} & \multirow{2}{*}{$\begin{array}{l}\text { Движимое } \\
\text { имущество } \\
\text { Количество } \\
\end{array}$} & \multirow{2}{*}{\begin{tabular}{|c|}
$\begin{array}{c}\text { Земельные } \\
\text { участки }\end{array}$ \\
Количество \\
\end{tabular}} & \multirow{2}{*}{\begin{tabular}{|c|}
$\begin{array}{c}\text { Пакеты акций } \\
\text { (доли) }\end{array}$ \\
Количество \\
\end{tabular}} \\
\hline & \multirow{2}{*}{$\begin{array}{l}\text { Всего } \\
\text { юридиче- } \\
\text { ских лиц, } \\
\text { ед. }\end{array}$} & \multirow{2}{*}{$\begin{array}{c}\text { Абсо- } \\
\text { лютный } \\
\text { прирост } \\
(+/-) \\
\end{array}$} & & & & \\
\hline & & & $\begin{array}{l}\text { Стоимость, } \\
\text { тыс. } \mathrm{p} .\end{array}$ & $\begin{array}{l}\text { Стоимость, } \\
\text { тыс. } \mathrm{p} \text {. }\end{array}$ & $\begin{array}{c}\text { Стоимость, } \\
\text { тыс. } \mathrm{p} .\end{array}$ & $\begin{array}{l}\text { Стоимость, } \\
\text { тыс. } \mathrm{p} .\end{array}$ \\
\hline \multirow{2}{*}{$\begin{array}{l}\text { Областные государ- } \\
\text { ственные казенные } \\
\text { учреждения }\end{array}$} & \multirow[b]{2}{*}{180} & \multirow[b]{2}{*}{ * } & * & * & * & \multirow[b]{2}{*}{$x$} \\
\hline & & & 42180352,4 & 1739064,4 & * & \\
\hline \multicolumn{7}{|c|}{ Коммерческие организации } \\
\hline \multirow{2}{*}{$\begin{array}{l}\text { Областные государ- } \\
\text { ственные унитарные } \\
\text { предприятия }\end{array}$} & \multirow[b]{2}{*}{5} & \multirow[b]{2}{*}{-1} & * & * & * & \multirow[b]{2}{*}{$x$} \\
\hline & & & * & * & * & \\
\hline \multirow{2}{*}{$\begin{array}{l}\text { Акционерные общества и } \\
\text { общества с ограниченной } \\
\text { ответственностью, всего }\end{array}$} & \multirow{2}{*}{18} & \multirow{2}{*}{+1} & \multirow{2}{*}{$x$} & \multirow{2}{*}{$x$} & \multirow{2}{*}{$x$} & 18 \\
\hline & & & & & & 4548092,53 \\
\hline \multirow{2}{*}{$\begin{array}{l}\text { В том числе } \\
100 \% \text { акций }\end{array}$} & \multirow{2}{*}{11} & \multirow{2}{*}{-1} & \multirow{2}{*}{$x$} & \multirow{2}{*}{$x$} & \multirow{2}{*}{$x$} & 10 \\
\hline & & & & & & 4503634,01 \\
\hline \multirow{2}{*}{ 50-99 \% акций } & \multirow{2}{*}{3} & \multirow{2}{*}{+1} & \multirow{2}{*}{$x$} & \multirow{2}{*}{$x$} & \multirow{2}{*}{$x$} & 3 \\
\hline & & & & & & 5058,52 \\
\hline $25-49$ \% акиий & 2 & 0 & $x$ & $x$ & $x$ & 2 \\
\hline & & & $x$ & $x$ & $x$ & 34400 \\
\hline По 24 \% акиий & 2 & +1 & $x$ & $x$ & $x$ & 2 \\
\hline До $24 \%$ акции & 2 & +1 & $x$ & $x$ & $x$ & 5000 \\
\hline
\end{tabular}

* Сведения в отчете отсутствуют.

В 2016 г. общее количество областных государственных учреждений составило 575 ед., из них казенных -180 ед. $(31,3 \%)$, бюджетных - 269 ед. (46,8\%), автономных - 126 ед. $(21,9 \%)$. Общее число областных государственных учреждений в отчетном году сократилось на 16 ед. $(-2,7 \%)$ по сравнению с 2015 г., на конец которого осуществляли деятельность 591 ОГУ.
Структура областных учреждений по типам в разрезе ведомств правительства Иркутской области представлена на рис. 1. В прочие органы власти Иркутской области включены: Агентство по обеспечению деятельности мировых судей; Аппарат губернатора Иркутской области; Управление делами губернатора Иркутской области; Архивное агентство; Служба по охране объектов культурного наследия.

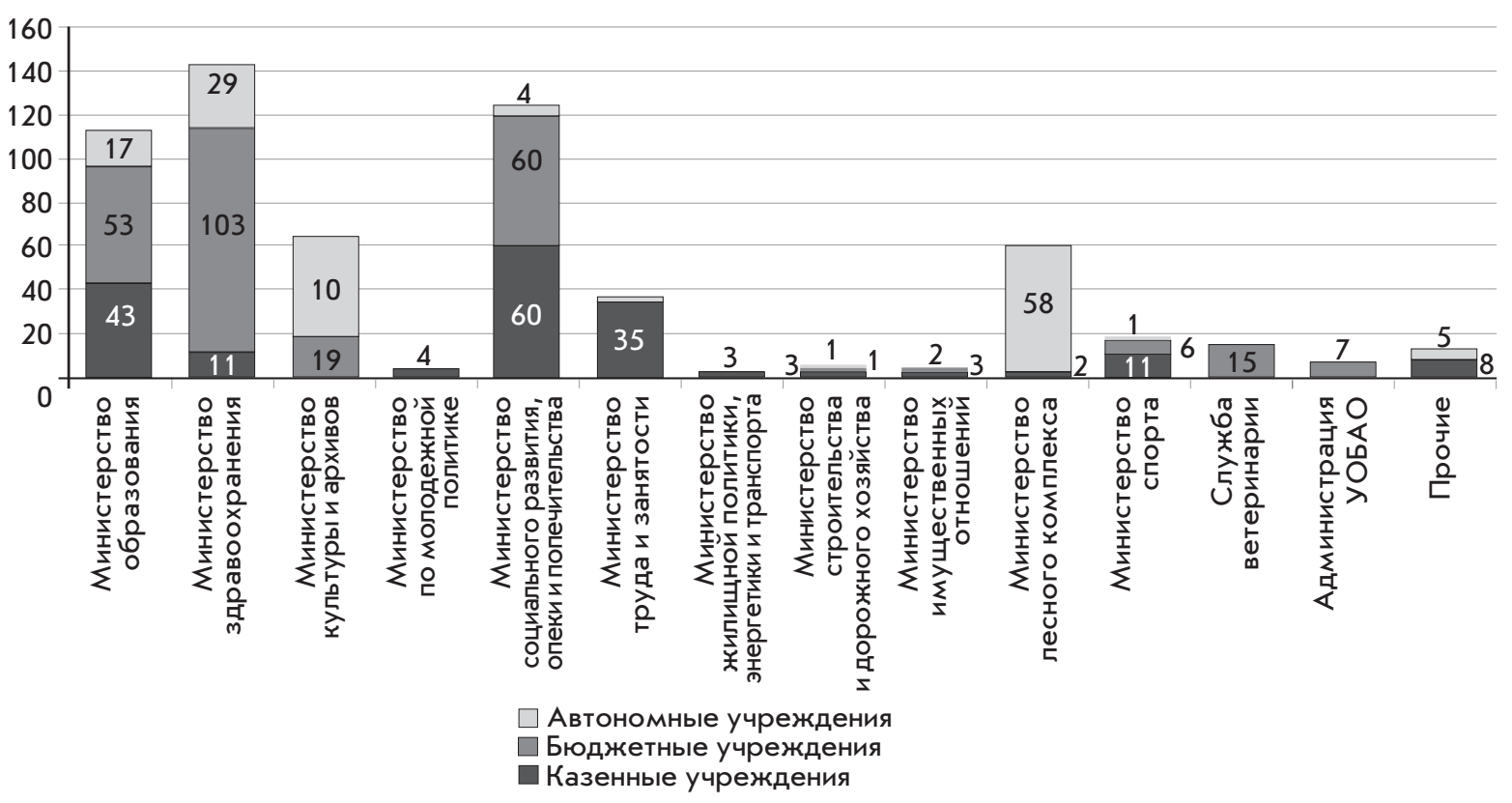

Рис. 1. Распределение ОГУ по ведомствам правительства Иркутской области в 2016 г.

Составлено по данным отчета правительства Иркутской области о распоряжении государственной собственностью Иркутской области за 2016 г. 
Основной функцией в сфрере управления имуществом ОГУ и ОГВ является организация работы по эффрективному и целевому использованию областного имущества, сохранению объектов, способствующих реализации полномочий органов власти Иркутской области, а также объектов, имеющих социальное и стратегическое значение.

На рис. 2 представлена структура площадей ОГУ Иркутской области в 2015 г. Почти 90,00 \% площадей ОГУ использовалось для осуществления основных видов уставной деятельности ОГУ; 3,25 \% площадей ОГУ не использовалось в связи с отсутствием потребности и (или) неудовлетворительным состоянием. При этом 3,77 \% площадей были арендованы ОГУ у сторонних организаций. 3 \% от общих затрат на содержание имущества ОГУ — годовые затраты бюджетаИркутской области на аренду помещений, необходимых для осуществления уставной деятельности ОГУ (среднегодовые затраты учреждений на содержание недвижимого имущества, находящегося на балансе учреждений, составили 3,3 млрд р.).

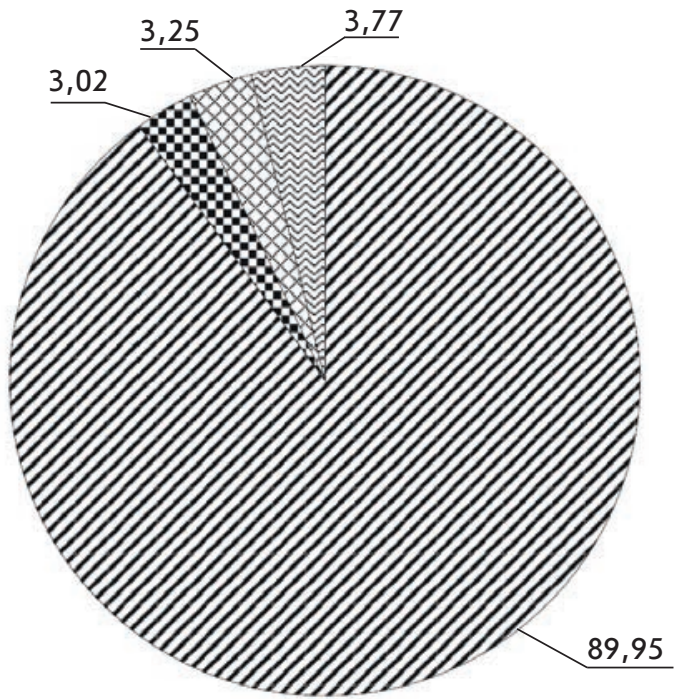

ஜ Площади ОГУ, используемые для осуществления уставной деятельности

จ Площади ОГУ, находящиеся в обременении

图 Площади, не используемые в связи с отсутствием потребности и (или) неудовлетворительным состоянием

图 Площади, арендованные ОГУ

\section{Рис. 2. Площади объектов ОГУ}

Иркутской области в 2015 г., \%

Составлено по данным отчета министерства имущественных отношений Иркутской области

о проделанной работе за 2015 г

URL: http://irkobl.ru/sites/mio/about/othet

Данные о структуре площадей объектов ОГУ за 2016 г. в отчетности не представлены, что не позволяет сделать сравнительный анализ использования площадей ОГУ. Известно, что уровень обременения имущества ОГУ в 2016 г. составил уже 19,18\%, что более чем в 6 раз выше уровня 2015 г.

Следует отметить, что устойчивая тенденция повышения уровня обременения имущества ОГУ является основанием для принятия решений о необходимости рассмотрения вопроса о возможности отчуждения части имущественного комплекса в областную казну и об оптимизации использования имущества ОГУ для достижения социально значимых целей.

В качестве ключевого показателя, отражающего результаты использования ОГУ имущественного комплекса, переданного им на праве оперативного управления, применяется уровень загрузки мощностей ОГУ, который отражает уровень фрактического использования площадей объектов недвижимого имущества ОГУ для осуществления уставной деятельности относительно максимально возможного объема предоставления услуг с учетом установленных ведомственных нормативов обеспеченности площадями объектов недвижимого имущества ОГУ на 1 ед. услуги².

В 2016 г. уровень загрузки мощностей ОГУ Иркутской области составил 88,60\%. Так, у ОГУ министерства спорта Иркутской области уровень загрузки мощностей составил лишь 43,76\%, что свидетельствует о недозагрузке более половины имеющихся в распоряжении площадей.

Низкий уровень загрузки мощностей ОГУ требует установления причин и разработки мероприятий по обеспечению вовлеченности данных площадей в хозяйственный оборот посредством их использования подведомственными учреждениями, в том числе передачи сторонним организациям в аренду, в безвозмездное пользование (обременения площадей объектов недвижимого имущества ОГУ), или их отчуждения у ОГУ.

Одной из основных причин, по которой площади ОГУ не вовлечены в процесс оказания социально значимых услуг и осуществления иных видов деятельности, может являться высокая степень их износа.

Степень износа объектов государственной собственности Иркутской области, находящихся на балансе ОГУ, в 2016 г. составила 59,3\%. 20,6 \% имущества, закрепленного за

${ }^{2}$ Например, число обучающихся на $1 \mathrm{M}^{2}$, исходя из строительных нормативов при проектировании общественных зданий. 
ОГУ, находится в крайне изношенном состоянии и требует капитального ремонта ${ }^{3}$.

Средний износ имущества ОГУ Иркутской области, по данным отчета, составил $64 \%$, при этом У ОГУ министерства строительства и дорожного хозяйства Иркутской области наблюдается самый высокий износ имущества в размере 95 \%. Высокий процент износа имущества и его вовлеченность в оказание услуг в таком состоянии ведут к снижению качества и доступности услуг для населения региона.

Новым подходом к представлению результатов использования объектов государственной собственности Иркутской области в 2016 г. стало применение в качестве оценочных показателей результативности и эффективности использования имущества областными государственными учреждениями системы индексов, в основе которых лежит сопоставление темпов роста по взаимосвязанным показателям. Значения показателей в динамике позволяют оценить тенденции изменения результатов использования областной собственностью ОГУ, сделать выводы о проблемах и направлениях повышения эффективности и результативности использования областной собственности, находящейся в оперативном управлении.

Фактические значения индексов за 2016 г. представлены на рис. 3.

\footnotetext{
${ }^{3}$ URL: http: / / www.irk.gov.ru/events/publications / mass-media /detail.php?ID $=17546$.
}

Индексами, значения которых в 2016 г. были ниже базового (нормативного), стали индекс прироста стоимости имущества ОГУ $(0,74)$, индекс использования имущества для основных видов деятельности ОГУ $(0,52)$, индекс исполнения бюджетных обязательств по расходам на содержание имущества ОГУ $(0,93)$, индекс бюджетной эфрфективности деятельности ОГУ $(0,64)$, что свидетельствует о том, что в 2016 г.:

- стоимость выбывших основных фондов ОГУ превысила стоимость введенных;

- темп роста уровня обременения имущества ОГУ был выше (в 1,5 раза), чем темп роста уровня загрузки имущества ОГУ;

- фактический объем исполненных расходных обязательств областного бюджета на содержание имущества ОГУ составил 93 \% от планового значения;

- темпы роста расходов областного бюджета на содержание имущества ОГУ существенно превысили темпы роста доходов областного бюджета от деятельности ОГУ.

Индексами, значения которых в 2016 г. были выше базового (нормативного), стали индекс воспроизводства основных фондов ОГУ $(1,61)$, индекс инвестирования ОГУ $(1,77)$, индекс годности имущества ОГУ $(1,53)$, это означает, что:

- темп роста коэфффициента ввода основных фрондов ОГУ превысил темп роста коэфрфициента их выбытия;

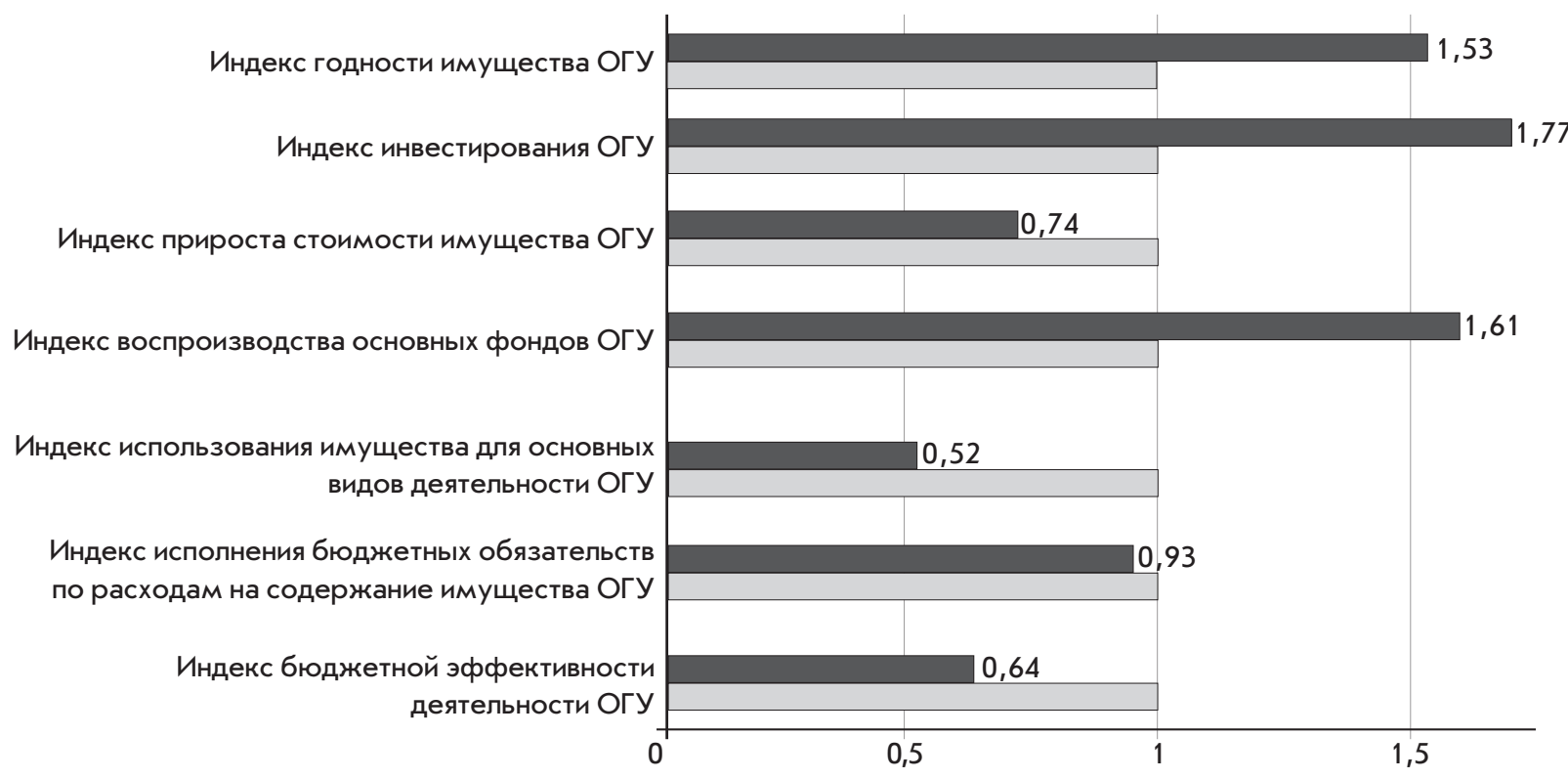

Рис. 3. Индексы результативности и эффективности использования областной собственности ОГУ Иркутской области за 2016 г.4

Составлено по данным отчета правительства Иркутской области о распоряжении государственной собственностью Иркутской области за 2016 г.

${ }^{4}$ За базовое значение индекса принимается 1. 
- темп роста объема инвестиций ОГУ в основные фонды ОГУ за счет собственных доходов ОГУ, полученных от приносящей доходы деятельности, существенно превысил темп роста объема бюджетных инвестиций в основные фонды ОГУ;

- темп роста общей площади объектов, переданных ОГУ, превысил темп роста площадей объектов, переданных ОГУ, которые признаны аварийными и (или) требующими капитального ремонта.

Что касается использования областного имущества, право хозяйственного ведения на которое передано унитарным предприятиям, то, по данным отчета, на начало 2017 г. в Реестре Иркутской области значится пять областных государственных унитарных предприятий. В 2016 г. в отношении ОГУП «Печатный дом Усть-Ордынский» завершена процедура конкурсного производства и предприятие исключено из Реестра.

Общая стоимость областного государственного имущества, закрепленного за
ОГУП на праве хозяйственного ведения, по состоянию на 31 декабря 2016 г. составляет 4479114 тыс. р., что достигает 9,88 \% в общей стоимости областной государственной собственности.

Сведения об областных государственных унитарных предприятиях и результатах их деятельности за 2016 г. представлены в табл. 2.

Отметим, что анализ нормативных актов, регламентирующих методики анализа деятельности ГУП в целом и эффрективности использования государственного имущества, закрепленного в хозяйственном ведении за ГУП, в частности, не дает исчерпывающего ответа на вопрос, по каким показателям следует проводить оценку [9-11].

Сведения о результатах использования областной государственной собственности областными государственными унитарными предприятиями 2016 г. представлены в табл. 3.

Сведения о государственных унитарных предприятиях Иркутской области

Таблица 2 и результатах их деятельности за 2016 г.

\begin{tabular}{|c|c|c|c|c|c|}
\hline Предприятие & $\begin{array}{c}\text { Основные } \\
\text { виды } \\
\text { деятельности }\end{array}$ & $\begin{array}{c}\text { Финансовый } \\
\text { результат } \\
\text { деятельности } \\
\text { (чистая } \\
\text { прибыль / } \\
\text { убыток) } \\
\end{array}$ & $\mid \begin{array}{c}\text { Размер устав- } \\
\text { ного фоонда } \\
\text { (изменение } \\
\text { за отчетный } \\
\text { период, }+/- \text { ) }\end{array}$ & $\begin{array}{c}\text { Соотношение } \\
\text { стоимости } \\
\text { чистых активов } \\
\text { к величине } \\
\text { уставного } \\
\text { капитала } \\
\end{array}$ & $\begin{array}{c}\text { Объем } \\
\text { прибыли, } \\
\text { перечис- } \\
\text { ленной } \\
\text { в областной } \\
\text { бюджет } \\
\end{array}$ \\
\hline ОГУЭП «Облкоммунэнерго» & $\begin{array}{l}\text { Распределение } \\
\text { электроэнергии }\end{array}$ & 298244 & 850000 & 4,5 & 0 \\
\hline ГУТПП «Фармация» & $\begin{array}{l}\text { Торговля } \\
\text { лекарственными } \\
\text { средствами }\end{array}$ & 2932 & 851 & 7,8 & 1084,1 \\
\hline ГУЭП «Облкоммунэнерго-Сбыт» & $\begin{array}{l}\text { Распределение } \\
\text { электроэнергии }\end{array}$ & 2008 & 23477 & 8,7 & 13,2 \\
\hline ОГУП «ОЦТИ-Областное БТИ» & $\begin{array}{l}\text { Кадастровая } \\
\text { деятельность }\end{array}$ & -5679 & 5580 & 0,3 & 200,4 \\
\hline
\end{tabular}

Показатели использования областной государственной собственности

Таблица 3 государственными унитарными предприятиями Иркутской области за 2016 г.

\begin{tabular}{|c|c|c|c|c|c|c|c|c|c|c|}
\hline \multirow{3}{*}{ Показатель } & \multicolumn{2}{|c|}{ Всего по ОГУП } & \multicolumn{8}{|c|}{ В том числе по предприятиям } \\
\hline & \multirow{2}{*}{ Значение } & \multirow{2}{*}{$\begin{array}{c}\text { Темп } \\
\text { роста, \% }\end{array}$} & \multicolumn{2}{|c|}{$\begin{array}{c}\text { ОГУЭП } \\
\text { «Облкоммунэнерго» }\end{array}$} & \multicolumn{2}{|c|}{$\begin{array}{c}\text { ГУТПП } \\
\text { «Фармация» }\end{array}$} & \multicolumn{2}{|c|}{$\begin{array}{c}\text { ГУЭП «Облком- } \\
\text { мунэнерго-Сбыт }\end{array}$} & \multicolumn{2}{|c|}{$\begin{array}{c}\text { ОГУП «ОЦТИ- } \\
\text { Областное } \\
\text { БТИ» } \\
\end{array}$} \\
\hline & & & Значение & $\begin{array}{c}\text { Темп } \\
\text { роста, \% }\end{array}$ & $\begin{array}{c}\text { Значе- } \\
\text { ние }\end{array}$ & $\begin{array}{c}\text { Темп } \\
\text { роста, } \\
\% \\
\end{array}$ & $\begin{array}{c}\text { Значе- } \\
\text { ние }\end{array}$ & $\begin{array}{c}\text { Темп } \\
\text { роста, \% }\end{array}$ & $\begin{array}{c}\text { 3наче- } \\
\text { ние }\end{array}$ & $\begin{array}{c}\text { Темп } \\
\text { роста, } \\
\%\end{array}$ \\
\hline $\begin{array}{l}\text { Объем неналого- } \\
\text { вых доходов об- } \\
\text { ластного бюджета } \\
\text { от деятельности } \\
\text { ОГУП, тыс. р. }\end{array}$ & 1297,7 & 31,67 & 0 & - & 1084,1 & 95,44 & 13,2 & - & 200,4 & 10,2 \\
\hline $\begin{array}{l}\text { Экономическая } \\
\text { рентабельность } \\
\text { активов ОГУП }\end{array}$ & 12,85 & - & 13,5 & 59,50 & 11,09 & 76,32 & 3,66 & 159,83 & 0 & 0 \\
\hline
\end{tabular}


Окончание табл. 3

\begin{tabular}{|c|c|c|c|c|c|c|c|c|c|c|}
\hline \multirow{3}{*}{ Показатель } & \multicolumn{2}{|c|}{ Всего по ОГУП } & \multicolumn{8}{|c|}{ В том числе по предприятиям } \\
\hline & \multirow{2}{*}{ Значение } & \multirow{2}{*}{$\begin{array}{c}\text { Темп } \\
\text { роста, \% }\end{array}$} & \multicolumn{2}{|c|}{$\begin{array}{c}\text { ОГУЭП } \\
\text { «Облкоммунэнерго» }\end{array}$} & \multicolumn{2}{|c|}{$\begin{array}{c}\text { ГУТПП } \\
\text { «Фармация» }\end{array}$} & \multicolumn{2}{|c|}{$\begin{array}{c}\text { ГУЭП «Облком- } \\
\text { мунэнерго-Сбыт» }\end{array}$} & \multicolumn{2}{|c|}{\begin{tabular}{|c|} 
ОГУП «ОЦТИ- \\
Областное \\
БТИ»
\end{tabular}} \\
\hline & & & Значение & $\begin{array}{c}\text { Темп } \\
\text { роста, \% }\end{array}$ & $\begin{array}{c}\text { Значе- } \\
\text { ние }\end{array}$ & $\begin{array}{c}\text { Темп } \\
\text { роста, } \\
\%\end{array}$ & $\begin{array}{c}\text { Значе- } \\
\text { ние }\end{array}$ & $\begin{array}{c}\text { Темп } \\
\text { роста, \% }\end{array}$ & $\begin{array}{c}\text { Значе- } \\
\text { ние }\end{array} \mid$ & $\begin{array}{c}\text { Темп } \\
\text { роста, } \\
\%\end{array}$ \\
\hline $\begin{array}{l}\text { Объем совокуп- } \\
\text { ных капитальных } \\
\text { вложений } \\
\text { в основные фонды } \\
\text { ОГУП, всего }\end{array}$ & 161777,8 & 30,86 & 161490,8 & 33,95 & 0 & 0 & 287 & 0,61 & 0 & 0 \\
\hline $\begin{array}{l}\text { В том числе } \\
\text { объем собствен- } \\
\text { ных инвестиций } \\
\text { ОГУП, тыс. р. } \\
\end{array}$ & 161777,8 & 33,72 & 161490,8 & 33,95 & 0 & 0 & 287 & 11,35 & 0 & 0 \\
\hline $\begin{array}{l}\text { Степень износа } \\
\text { имущества } \\
\text { ОГУП, \% }\end{array}$ & 82,88 & - & 83,15 & 101,69 & 63,00 & 105,35 & 41,63 & 124,38 & - & - \\
\hline $\begin{array}{l}\text { Коэфффициент } \\
\text { ввода основных } \\
\text { фондов ОГУП, \% }\end{array}$ & 0,95 & - & 0,95 & 38,78 & 0 & 0 & 0,87 & 2,22 & - & - \\
\hline \begin{tabular}{|l} 
Коэфффициент \\
выбытия основных \\
фондов ОГУП \\
в результате \\
их списания, \%
\end{tabular} & 0,028 & - & 0,001 & 3,330 & 5,670 & 88,870 & 3,500 & 17,200 & - & - \\
\hline
\end{tabular}

Коэффициент износа имущества ОГУП по состоянию на 31 декабря 2016 г. составил 82,88 \%. Из ОГУП, осуществляющих финансово-хозяйственную деятельность в отчетном периоде, наибольший износ имущества наблюдается у ОГУЭП «Облкоммунэнерго», коэфффициент износа составил $83,15 \%$, что выше среднего значения по отрасли более чем на $20 \%$ (60-70\%). Существенного движения основных фондов в структуре имущества в 2016 г. не происходило. Об этом свидетельствуют низкие значения коэффрициента ввода основных фондов ОГУП (0,95\%), коэфффициента выбытия основных фондов ОГУП в результате их списания $(0,028 \%)$.

Выручка областных государственных унитарных предприятий по итогам работы за 2016 г. составила 3602361 тыс. р., что выше уровня аналогичного периода прошлого года на 39,59\%.

По итогам работы за 2016 г. положительный финансовый результат имеют три предприятия: ОГУЭП «Облкоммунэнерго», ГУТПП «Фармация», ГУЭП «Облкоммунэнерго-Сбыт».

Согласно закону Иркутской области «Об областном бюджете на 2016 год" от 23 декабря 2015 г. № 130-03, прогнозируемые доходы областного бюджета на 2016 г. от перечисления части прибыли ОГУП, остающейся после уплаты налогов и обязательных платежей, составляли 1 295,0 тыс. р. Фактически поступило в бюджет по состоянию на 31 декабря 2016 г. 1297,7 тыс. р., что составляет 100,2 \% выполнения плана.

Эфрфективность государственных и муниципальных унитарных предприятий должна быть никак не ниже, чем у коммерческих организаций других организационно-правовых форм [9]. Поэтому в качестве ключевого показателя использования имущества ОГУП была определена экономическая рентабельность активов ОГУП как отдача в виде EBITDA на каждый рубль стоимости совокупных активов ОГУП на конец отчетного периода. Средний уровень экономической рентабельности ОГУП Иркутской области составляет 12,85 \%. Следует отметить, что темпы роста экономической рентабельности ОГУЭП «Облкоммунэнерго» и ГУТПП «Фармация» имеют отрицательные значения - 59,5 и 76,32\% соответственно, при том что абсолютное значение показателей экономической рентабельности этих предприятий находится на уровне выше или близком к среднему. ГУЭП «Облкоммунэнерго-Сбыт» при низком значении показателя (3,66 \%) продемонстрировал высокий темп роста - 159,83\%. 
По мнению авторов, результаты использования объектов государственной собственности, переданных экономическим агентам, должны отражать не только результаты использования областного имущества государственными учреждениями и государственными унитарными предприятиями, но и хозяйственными обществами, пакеты акций (доли) которых находятся в государственной собственности. Переданные ХО объекты государственной собственности в виде вклада в уставный капитал становятся собственностью XO, при этом возникает новый объект областной государственной собственности - пакет акций (доля). Поэтому сведениями о результатах использования государственной собственности ХO, пакеты акций (доли) которых находятся в собственности ИО, являются следующие показатели: рентабельность собственного капитала XO, уровень доходности на одну акцию ХO, финансовый результат деятельности (чистая прибыль/убыток), соотношение стоимости чистых активов к величине уставного капитала, дивиденды.

По состоянию на 31 декабря 2016 г. Иркутская область являлась акционером и участником 18 хозяйственных обществ. Доля хозяйственных обществ, завершивших финансовый год с прибылью, составила 44,44 \% (восемь хозяйственных обществ).

Следует отметить, что в российской экономической литературе встречаются разные мнения относительно государственного участия в экономике, в том числе посредством участия в капитале хозяйственных обществ. К государственному имуществу в этом случае относятся приносящие доход активы, в том числе и акции. Это особая сфера функционирования государственной собственности, где отчетливо проявляется отсутствие контроля со стороны социального субъекта общенародного уровня. Это проявляется в низкой доходности корпоративных акций, принадлежащих государству. В компаниях со смешанной собственностью интерес представителей частного капитала значительно мотивированнее представителей государства [12, с. 34].

Совокупный финансовый результат по хозяйственным обществам с участием Иркутской области является положительным, прибыль составила 429,3 млн р. (АО «Международный аэропорт Иркутск», AO «Корпорация развития Иркутской области», АО «Иркутская областная оптово-снабженческая аптечная база», AO «Дорожная служба Иркутской области», АО «Гостиничный комплекс «Русь», АО «Байкальская пригородная пассажирская компания», АО «Иркутское региональное жилищное агентство», ОАО «СибЭкспоЦентр»).

В 2016 г. дивиденды по акциям перечислены шестью хозяйственными обществами, общая сумма поступлений составила 86,4 млн р., что в 1,3 раза меньше по сравнению с аналогичным периодом предыдущего года.

По результатам деятельности за 2016 г. отрицательное значение рентабельности собственного капитала имеет АО «Байкальская пригородная пассажирская компания» $(-4,54$ \%). АО «Иркутская областная оптово-снабженческая аптечная база» имеет наиболее высокое значение рентабельности собственного капитала - 20,7\%.

Проблема реализации государственных интересов и оценки результатов деятельности обществ представляется более сложной для ХО со стопроцентным государственным участием. В структуре объектов учета Иркутской области таких ХО 56 \%. По мнению авторов, в данном случае система оценки результатов деятельности ХO с государственным участием, кроме традиционных показателей финансово-хозяйственной деятельности, должна включать и оценку доли работ по государственным контрактам ХО, выполненных собственными силами, для оценки вовлеченности таких обществ в процесс реализации государственных нужд.

По данным отчета, в 2016 г. из 18 хозяйственных обществ только три акционерных общества (АО «Иркутская областная оптово-снабженческая аптечная база», АО «Дорожная служба Иркутской области», АО «Коммунальные инженерные системы») имеют долю работ по государственным контрактам, выполненных собственными силами, выше 60 \%. Этот показатель для ООО «Телекомпания «Альтернативная Иркутская Студия Телевидения» составил только 29,78 \%, для АО «СибЭкспоЦентр» - 7,9\%. Остальные ХО либо вообще не были привлечены к выполнению государственных контрактов, либо доля их участия в выполнении государственного контракта не превышала $1 \%$.

Доходы - важнейший элемент экономической реализации собственности и интересов. Общая структура доходов областного бюджета от использования и распоряжения государственной собственностью Иркутской области в 2016 г. представлена на рис. 4. 


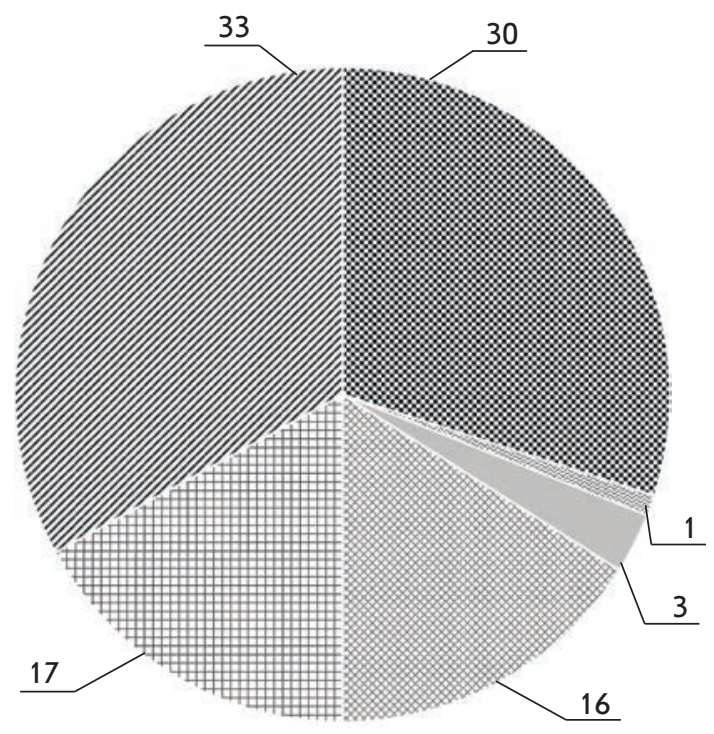

จ В виде прибыли, приходящейся на доли в уставных капиталах XO, или дивидендов по акциям, принадлежащим области

Доходы от продажи имущества, находящегося в областной собственности

四 Доходы от сдачи в аренду имущества ОГУ и ОГВ

Доходы от сдачи в аренду имущества, составляющего областную казну

$\square$ Доходы от аренды земли, находящейся в областной собственности

园 Часть прибыли ОГУП, пречисленная в областной бюджет

Рис. 4. Структура доходов областного бюджета от использования и распоряжения государственной собственностью Иркутской области, \% ${ }^{5}$

Составлено по данным отчета правительства Иркутской области о распоряжении

государственной собственностью Иркутской области за 2016 г.

Таким образом, доходы от использования областного имущества Иркутской области в структуре доходов областного бюджета за 2016 г. не превышают 50 \%.

В ходе анализа результатов использования объектов государственной собственности Иркутской области за 2016 г. авторы столкнулись с проблемой неполноты представленных в отчете сведений. Кроме того, достоверность значений ряда показателей вызывает сомнения. Это, в свою очередь, не позволяет сделать обоснованные выводы о результативности и

5 Данные о доходах областного бюджета от деятельности ОГУ Иркутской области за 2016 г. в отчете не представлены. эфффективности использования областной государственной собственности.

Проблема актуальности и достоверности данных отчета обусловлена в том числе неудовлетворительной работой правительства Иркутской области по организации сбора первичных данных с подведомственных организаций по объектам учета.

Для повышения качества управления государственной собственностью Иркутской области, принятия обоснованных эффрективных решений в сорере имущественно-земельных отношений необходима комплексная система контроля за использованием областной собственности, которая представляла бы собой интеграцию технических средств мониторинга, профрессиональных компетенций и методической базы оценки эффрективности использования объектов областной собственности.

В целях упорядочивания и совершенствования нормативной базы оценки деятельности хозяйствующих субъектов, являющихся объектами учета областной собственности, необходимо разработать:

- методические указания по оценке эффективности деятельности областных государственных учреждений;

- методические указания по оценке эффективности деятельности областных государственных унитарных предприятий;

- методические указания по оценке эффективности деятельности хозяйственных обществ, пакеты акций (доли) которых находятся в областной государственной собственности.

Необходимо разработать организационный механизм межведомственного взаимодействия в рамках мониторинга эффрективности и рационального использования государственной собственности Иркутской области с участием минэкономразвития Иркутской области, а также отраслевых ведомств, в том числе посредством разработки и упорядочения процедур сбора и обработки первичных данных в разрезе ведомств.

Реализация предложенных мер позволит совершенствовать систему управления в части контроля за использованием областного имущества, будет способствовать успешной реализации областной государственной политики и современной концепции управления государственной собственностью Иркутской области.

\section{СПИСОК ИСПОЛЬЗОВАННОЙ ЛИТЕРАТУРЫ}

1. Капелюшников Р. И. Экономическая теория прав собственности (методология, основные понятия, круг проблем) / Р. И. Капелюшников. - М. : Изд-во ИМЭМО РАН, 1990. - 90 с.

2. Управление государственной собственностью субъекта Российской Федерации: концептуальная модель / под ред. С. А. Кочетковой. - Саранск : Изд-во Морд. ун-та им. Н.П. Огарева, 2013. - 184 с.

3. Соловьев М. М. Проблемы оценки эффективности управления государственной собственностью / М. М. Соловьев, Л. И. Кошкин / / Менеджмент в России и за рубежом. - 2008. - № 4. - С. 32-46. 
4. Маркварт Э. Эффрективность управления публичной собственностью: понятие, подходы, критерии / Э. Маркварт / / Проблемы теории и практики управления. - 2014. — № 6. - С. 17-26.

5. Лепихина О. Ю. Разработка модели данных единой информационной системы учета, мониторинга и оценки эффективности использования федерального имущества образовательных учреждений / О. Ю. Лепихина, Е. А. Рязанова / / Альманах современной науки и образования. - 2016. — № 2 (104). - С. 82-87.

6. Рахимов Т. Р. Эффеективность процесса и результата в социально-экономических системах / Т. Р. Рахимов / / Вестник науки Сибири. - 2015. - № 3 (18). - С. 11-19.

7. Ануфриева А. А. Анализ системы контроля за распоряжением государственной собственностью Иркутской области / А. А. Ануфриева, Н.С.Девятова / / Стратегические аспекты публичного управления и территориального развития : материалы ежегод. междунар. науч.-практ. конф., Иркутск, 27-28 апр. 2017 г. - Иркутск : Изд-во БГУ, 2017. - С. 56-63.

8. Абазова Л. Х. Проблемы в системе отношений собственности и возможные пути их решения / Л. Х. Абазова / / Актуальные вопросы экономических наук. - 2016. - № 55-1. - С. 129-133.

9. Баранова И. В. Система показателей эфффективности деятельности государственных унитарных предприятий / И. В. Баранова / / Сибирская фринансовая школа. - 2006. - № 1 (34). - С. 20-25.

10. Девятова Н. С. Совершенствование системы оценки деятельности государственных и муниципальных унитарных предприятий в России / Н. С. Девятова, В. А. Шишкин / / Государственное и муниципальное управление в XXI веке: теория, методология, практика : сб. материалов 29-й междунар. науч.-практ. конф., Новосибирск, 12 мая - 20 июня 2017 г. - Новосибирск : Центр развития научного сотрудничества, 2017. - С. 52-60.

11. Полянская Н. М. Оценка эфффективности использования ресурсов как инструмент государственной экономической политики региона: методологические аспекты / Н. М. Полянская, Э. Б. Найданова / / Современные проблемы науки и образования. - 2015. - № 2 (1). - С. 304-311.

12. Хубиев К. А. Государственный фактор экономического развития и новой индустриализации / К. А. ХУбиев // Экономическое возрождение России. - 2017. — № 1 (51). - С. 27-38.

\section{REFERENCES}

1. Kapelyushnikov R. I. Ekonomicheskaya teoriya prav sobstvennosti (metodologiya, osnovnye ponyatiya, krug problem) [Economic theory of property rights (methods, basic notions, range of issues)]. Moscow, Institute of World Economy and International Relations Publ., 1990.90 p.

2. Kochetkova S. A. (ed.). Upravlenie gosudarstvennoi sobstvennost'yu sub"ekta Rossiiskoi Federatsii: kontseptual'naya model' [Subject public property management of a Russian Federation constituent unit: conceptual model]. Saransk, Ogarev Mordovia State University Publ., 2013. 184 p.

3. Solovev M. M., Koshkin L. I. Issues of assessing state property management efficiency. Menedzhment $v$ Rossii i za rubezhom = Management in Russia and Abroad, 2008, no. 4, pp. 32-46. (In Russian).

4. Markvart E. Efficiency of public property management: notion, approaches, criteria. Problemy teorii i praktiki upravleniya $=$ Theoretical and Practical Aspects of Management, 2014, no. 6, pp. 17-26. (In Russian).

5. Lepikhina O. Yu., Ryazanova E. A. Development of the data model of a unified information system for accounting, monitoring and evaluating efficiency of educational institution federal property use. Al'manakh sovremennoi nauki $i$ obrazovaniya = Almanach of contemporary science and education, 2016, no. 2 (104), pp. 82-87. (In Russian).

6. Rakhimov T. R. Effectiveness and efficiency in socio-economic systems. Vestnik nauki Sibiri = Siberian Journal of Science, 2015, no. 3 (18), pp. 11-19. (In Russian).

7. Anufrieva A. A., Devyatova N. S. Analysis of the control system of the Irkutsk Oblast public property management. Strategicheskie aspekty publichnogo upravleniya i territorial' nogo razvitiya. Materialy ezhegodnoi mezhdunarodnoi nauchno-prakticheskoi konferentsii, Irkutsk, 27-28 aprelya $2017 \mathrm{~g}$. [Strategic aspects of public administration and territorial development. Materials of International Research Conference, Irkutsk, April 27-28, 2017]. Irkutsk, Baikal State University Publ., 2017, pp. 56-63. (In Russian).

8. Abazova L. Kh. Problems in the property relation system and possible ways out. Aktual'nye voprosy ekonomicheskikh nauk = Topical Issues of Economic Sciences, 2016, no. 55-1, pp. 129-133. (In Russian).

9. Baranova I. V. System of indicators of state unitary enterprise performance efficiency. Sibirskaya finansovaya shkola = Siberian Financial School, 2006, no. 1 (34), pp. 20-25. (In Russian).

10. Devyatova N. S., Shishkin V. A. Improving the performance assessment system of state and municipal unitary enterprises in Russia. Gosudarstvennoe i munitsipal'noe upravlenie v XXI veke: teoriya, metodologiya, praktika. Sbornik materialov 29-i Mezhdunarodnoi nauchno-prakticheskoi konferentsii, Novosibirsk, 12 maya - 20 iyunya $2017 \mathrm{~g}$. [Federal and municipal administration in the 21 st century: theory, methods, practice. 29th International Applied Research Conference Proceedings, Novosibirsk, May 12 - June 20, 2017]. Novosibirsk, Scientific Cooperation Development Center Publ., 2017, pp. 52-60. (In Russian).

11. Polyanskaya N. M., Naidanova E. B. Evaluation of resource use efficiency as a tool of state economic policy of the region: methodological aspects. Sovremennye problemy nauki i obrazovaniya $=$ Modern problems of science and education, 2015, no. 2 (1), pp. 304-311. (In Russian).

12. Khubiev K. A. State factor of the economic development and new industrialization. Ekonomicheskoe vozrozhdenie Rossii = The Economic Revival of Russia, 2017, no. 1 (51), pp. 27-38. (In Russian).

\section{Информация об авторах}

Ануфриева Алена Александровна - кандидат экономических наук, доцент, кафедра экономики и государственного управления, Байкальский государ-

\section{Authors}

Alena A. Anufrieva - PhD in Economics, Associate Professor, Economics and Public Administration Department, Baikal State University, 11 Lenin St. , 664003, 
ственный университет, 664003, г. Иркутск, ул. Ленина, 11, e-mail: alena-a2002@mail.ru.

Девятова Наталья Сергеевна - кандидат экономических наук, доцент, кафедра экономики и государственного управления, Байкальский государственный университет, 664003, г. Иркутск, ул. Ленина, 11, e-mail: devytova@mail.ru.

\section{Для цитирования}

Ануфриева А. А. Оценка результатов использования государственной собственности Иркутской области / А. А. Ануфриева, Н. С. Девятова // Известия Байкальского государственного университета. - 2018. - T. 28, № 1. - C. 12-23. - DOI: $10.17150 / 2500-2759.2018 .28(1) .12-23$.
Irkutsk, the Russian Federation, e-mail: alena-a2002@ mail.ru.

Natalia S. Devyatova - PhD in Economics, Associate Professor, Economics and Public Administration Department, Baikal State University, 11 Lenin St., 664003, Irkutsk, the Russian Federation, e-mail: devytova@mail.ru.

\section{For citation}

Anufrieva A. A., Devyatova N. S. Evaluating Efficiency of Irkutsk Oblast Public Property Use. Izvestiya Baykal'skogo gosudarstvennogo universiteta $=$ Bulletin of Baikal State University, 2018, vol. 28, no. 1, pp. 12-23. DOI: 10.17150/2500-2759.2018.28(1).12-23. (In Russian). 